\title{
CITIES, ANCIENT, AND DAILY LIFE
}

\author{
Charles Gates, Bilkent University, Ankara, Turkey
}

(c) 2008 Elsevier Inc. All rights reserved.

\section{Glossary}

atrium In a Roman house, an unroofed room with a basin below. ostrakon A fragment of pottery or stone on which something has been written or drawn.

peristyle court In Greek and Roman architecture, a courtyard surrounded by a colonnaded portico.

stele (pl. stelai, stelae) A stone slab, usually thin in section, placed vertically; often decorated with inscriptions, relief sculptures, and/or paintings.

tell An artificial mound consisting of the remains of settlements, especially the air-dried mud brick favored as a building material. Arabic tell $=$ Persian tepe, Turkish höyük.

\section{Ancient Cities Defined}

Cities arose fairly recently in the long history of humankind. Changes in climate c. 12000 years ago led to the end of the Ice Ages, to a warmer, moister climate that in certain parts of the world favored the development of controlled agriculture and animal husbandry. No longer were people dependent on the collecting or hunting of wild food sources. Thanks to agriculture, in particular, permanent, year-round settlements developed. As farmers settled together in small villages, as food surpluses were registered, certain people were freed for other tasks - crafts, religious activities, etc. Increase in population eventually resulted in cities, with such features as monumental public architecture, figural art, writing, and social stratification.

These changes, and the rise of cities, occurred at different times in different parts of the world, with many regions never having cities at all. The earliest cities appeared in the Near East. Here, the changes described above began to take place in the eleventh to tenth millennia BC. By the fourth millennium BC, developed cities had appeared. This article focuses on cities in this region - the Near East, Egypt, and the Mediterranean basin - with a concluding section on Teotihuacan (Mexico), as a New World comparison.

\section{Daily Life Defined}

'Daily life' in ancient cities comprises many elements. The polarity between private and public is one basic way to structure any study. Private life centers on the house. The architecture and objects (furniture, decorations, utensils, and tools) suggest family relationships and activities happening in the house. Gender and age relationships are important: male and female, and children, mature adults, and the elderly. The life cycle with its rites of passage can serve as a focus: birth, marriage, old age, death. Household functions include food preparation and eating (or dining), hygiene, sleeping, socializing, etc.

The public arena centers on social relationships, political organization, and the maintenance of order, economic matters (making a living, commerce and trade), and religion. Within a social hierarchy, different ranks in society, from rulers to slaves, have their various occupations. Other functions of city life were also public: religious practices, for one, and certain entertainments, such as the Roman bath. But like private life, public life takes place in a physical setting: buildings, monuments, streets, open spaces, perhaps in connection with certain natural features (rivers, hills, mountains, the sea, harbors). What these elements look like, individually and in relation with others, is an essential part of recreating daily life in ancient cities.

\section{The Archaeology of Daily Life in Cities}

\section{Archaeology as a Source of Information}

The possibility of stepping into vanished worlds has a great appeal. Archaeology, by exposing ruined cities, their buildings and their artifacts, is an important vehicle for making this possible. For many, a visit to an archaeological site is more exciting if one gets the sense of what living there in a past time period was like. But for historic periods, ancient texts have also been a prime source of information about ancient life. The Hebrew Bible and Greek and Latin literature contain infinite details, combined with the names of people and places. Ancient Near Eastern, Egyptian, and Mayan texts, now readable thanks to decipherments in the nineteenth and twentieth centuries, also offer much. For some, the written word is supreme; the reality of place and object, the discipline of archaeology, are supplementary to the texts. These preferences can be reflected in the structures of academic study in universities, museums, and research centers.

We who wish to enter ancient worlds should not feel forced to choose, for each source of information makes a valuable contribution. We might well ask, though, what do archaeological excavations contribute that literary sources cannot? Archaeology, the study of material culture, makes clear the visual and the tactile. Ancient sounds (music), ancient smells 
(perfumes, cooked foods, fuels), ancient tastes (foods, wines, other drinks) are lost to us. Actions of all sorts and communications between people are recorded in texts, and we can perhaps visualize them taking place. But archaeology gives us the physical environment in which we can place the people and events we read about: the natural setting, the built environment (the city, its plan, its architecture), and the objects that ancient peoples created.

\section{The Preservations of Material Remains}

The material remains from ancient times are never preserved in their entirety. Climatic, geological, and cultural conditions all play a part in preserving and destroying. A dry climate, such as that of Egypt, preserves organic materials well. In contrast, in a wet, damp climate, the human body and products from animals' bodies (leather, hair), wood and other plant products, and even metal objects rot, rust, corrode, disintegrate. The state of preservation affects our understanding of particular cultures. Textiles, for example, were an important product of daily life and commercial exchange, but they never survive with the completeness of a stone sculpture.

Geological factors also have impact. Earthquakes, fires, volcanic eruptions, tidal waves, erosion, and the repeated flooding of silt-bearing rivers (such as the Nile) all have the potential to change the urban landscape. Human agency also has contributed to the alterations in the material record. In cities occupied for centuries, the building materials of structures collapsed or destroyed might be recycled into new constructions.

At the very least, foundations of buildings typically remain. Another standard remnant of ancient city life is broken pottery, for ceramics, products of a technology first developed in the mid-Neolithic period (eighth millennium BC), do not disintegrate. Other cultural habits that have preserved artifacts include the placing of objects in tombs and the depositing of offerings in religious centers.

\section{Variations of Research Design: Effects on Understanding Ancient Daily Life}

The questions that archaeologists seek to answer are hugely varied. They can be shaped by the state of research in a particular region or time period, its pasttraditions and current problems, and by the academic training of the individual researcher. In the Mediterranean, Egypt, and the Near East, approaches have included antiquarianism, the historical-descriptive, and the anthropological. These should not be seen as mutually exclusive, but overlap and complement each other, depending on the interests of the particular researcher.
Antiquarianism refers to an interest in an object by itself, a thing of beauty or curiosity. Compiling collections was often its goal. Today this term is negative, for it suggests that the interest in the object is shallow, divorced from any scientific study of the object's value in understanding the past.

A historical-descriptive approach has dominated the archaeology of our region in the past two centuries. Archaeologists seek to understand the material record by creating a framework for its study: by describing buildings and artifacts carefully, then by arranging them in chronological (or historical) order, and by seeing developments through time (diachronical): 'what', 'when', 'where'. With such classifications in hand, scholars can then compare and contrast developments between sites, between regions, between time periods. In our region, such comparisons are generally made within a particular civilization (Egyptian, Greek, Roman). For the study of the material evidence of daily life, this approach has been essential.

Anthropological approaches, applied especially to prehistoric cities, seek to understand the material record as a reflection of human behavior. While historical-descriptive analyses are not ignored but valued as helpful tools, the archaeologist focuses on larger questions, such as 'how' and 'why'. In addition, the anthropologist is interested in comparing situations between different civilizations, to extract larger lessons about the nature of human societies.

\section{Case Studies}

In order to explore further the issues raised above, let us examine five archaeological sites that are particularly well known for evidence concerning daily life, both from the Old World and the New. With our Old World examples, we shall proceed in reverse chronological order, from later to earlier.

\section{Pompeii}

Pompeii, near Naples (Italy), is justly famous for its rich evidence for daily life. This provincial Roman city, founded in the late sixth century BC, was destroyed in AD 79 by the eruption of the volcano Vesuvius, buried under volcanic pumice and ash (see Volcanism and Archaeology). Despite some salvage, looting, and sporadic occupation, the city was never dug out and reinhabited. Thanks to the building materials of stone, brick, and concrete, the architectural fabric of the city did not disintegrate, but remained remarkably well preserved, offering us an unparalleled glimpse into Roman city life in the late Republic and early Empire. Excavations began here in 1748, among the earliest of organized archaeological expeditions anywhere, and have continued to the present. 
The walled city housed a population of $c .10000$ 20000 . For the most part, the city was laid out on a grid plan, with the earliest sector, the 'forum' (city center) in the southwest. The forum and its environs contained the most important public buildings of the city. A long, narrow rectangular space, the open-air forum was lined by colonnaded porticoes. At the north, short end, stood the Temple of Jupiter, the major shrine of the city. Behind the porticoes lay civic, commercial, and additional religious buildings. Civic buildings at the south end of the forum offered meeting space for the town council, chief magistrates, and the police. Commercial buildings, on the east, included a guild hall for wool processors (Eumachia's building) and meat and fish market. Religious buildings consisted of a Temple to Apollo and a shrine to the deified emperor Vespasian. Emperors were routinely worshipped as divinities; the cult of the deified emperor served to link towns throughout the vast empire.

Archaeology at Greek and Roman sites has often concentrated on grand public buildings, so the view of ordinary street life that Pompeii gives is exceptional. Streets here had sidewalks and large stepping stones at intersections so one could step over any mud or sewage. Shops were frequent. They included a mill and a bakery, with stone mills for grinding flour and an oven for baking bread, and wine shops or snack bars with huge clay jars embedded in the counters for easy serving of beverages. Street walls were covered with advertisements and graffiti on all sorts of topics, such as politics, sex, and love, with many people named.

Pompeii had its own theaters, like all Roman cities. Types included a large, open-air half circle, a design taken from Greek tradition; the odeum, a smaller covered theater; and the amphitheater (lit. 'double theater'), here a large oval, used for the gladiatorial combats, the violent spectacles enjoyed by the Romans. A barracks for gladiators was identified in a portico behind the large theater, thanks to finds of helmets, armor, weapons, and graffiti referring to teams of gladiators. Nearby, skeletons of at least 52 people, including children, were found, together with much jewelry; they were gathered here intending to escape through the nearby city gate to the harbor, but never made it.

The private houses, numerous and well preserved, range in size and decoration from large and rich to modest. They typically have a lararium, a shrine to the lares, the deities who protected house and family. Traditional Italic houses feature the 'atrium', a room with a square or rectangular opening in the ceiling, letting in light, air, and rain. The rain would fall into a basin below, then into a connected underground water tank. Arranged around the atrium were smaller rooms. Since furniture was portable, the functions of these rooms could easily vary. In winter, they could be closed off, heated with portable braziers. At the rear, the important rooms were located, the main reception room (tablinum), where the owner of the house and his family formally greeted guests, and the dining room (triclinium). Houses of the wealthy might also have a 'peristyle' court, an open space surrounded by a colonnaded portico. A feature borrowed from Greek architecture, the peristyle in Roman Pompeii typically enclosed a garden. Explorations of the cavities left by plant roots, by pouring plaster down them to recover their shapes, have allowed researchers to reconstruct the kinds of plants cultivated, and to replant some gardens in the ancient manner.

House decorations typically included walls plastered and painted with a variety of images in a realistic style, and floor mosaics. A spectacular example of the latter is the Alexander Mosaic, a large $\left(5.1 \times 2.7 \mathrm{~m}^{2}\right)$ scene of Alexander the Great confronting the Persian king Darius III at the Battle of Issos.

\section{The Athenian Agora}

Our second example is the agora, or city center, of Athens (Greek agora = Latin forum). Unlike Pompeii, Athens has been continuously inhabited since antiquity - a situation that presents numerous practical problems to the archaeologist. The agora, located on low ground to the northwest of the acropolis, or high city, was covered with modern houses when excavations began in 1931. Over the years to the present, land has been bought, houses demolished, inhabitants and businesses relocated in order that this important sector of the ancient city be brought to light. Although the excavations have revealed remains from hundreds of years, from the Bronze Age well into the Middle Ages, the Athenian agora is distinctive for the quantity of written records that have helped in understanding the findings. Frequent mentions in ancient literary texts, notably a detailed description by Pausanias, a second century $\mathrm{AD}$ traveller, have been complemented by over 7500 inscriptions, on stone and on potsherds, discovered here. Ruins and texts together give a detailed view of the public life of ancient Athens.

What did this city center look like and what went on here? Let us concentrate on the fifth century BC, the golden age of ancient Athens. The Persians had sacked the city in 480 BC. Rebuilding soon began in the agora. Boundary stones marked the entrances; two found in situ were inscribed, "I am the boundary of the Agora." In mid century, a Temple to Hephaistos was built on the western hill that overlooks the Agora. Along the base of this hill, major civic buildings were 
erected: two bouleuterions, old and new, for meetings of the 500-member city council; a tholos, or round building, for the monthly delegation of 50 council members that ran the daily affairs of the city; and 'stoas', or free-standing porticoes, offering shelter from sun and rain for a variety of commercial and legal activities. The south side of the agora was framed by an additional stoa, an enclosure for law courts, a fountain house (where the public could obtain fresh water), and a mint (coinage, invented in Lydia, in western Asia Minor, in the late seventh century BC, had quickly become a standard feature in Greek cities). The north side was marked by a stream, and, in the northwest, by the painted stoa, in which panel paintings (now lost) depicted the Greek victory over the Persians at the Battle of Marathon. Private houses and shops, randomly placed, formed the east side. Cutting diagonally across the central space was the Panathenaic Way, the processional route to the Acropolis used during the annual festival for Athena, the patron goddess of the city. To the southwest of the agora lay a prison, houses, and workshops representing a wide range of industries: pottery, terracotta figurines, metalworking, sculpture and marble-working, shoemaking, and wine shops.

Of the many objects found in the Agora, those dealing with voting are particularly striking. They include ostraka, potsherds inscribed with the names of men whom people felt should be voted into exile because they were suspected of plotting to seize the government. This practice of ostracism was used from c. 487 to $415 \mathrm{BC}$, in Athens. Another fascinating item is a fragment of an allotment machine used for the selection of jurors and magistrates, a stone slab containing rows of slots for the tags of potential jury members. A crank system released a ball from a tube full of black and white marble balls. If white, the first row of jurors would serve that day. If black, that row would not serve. And on it went, ball after ball, until the required number of jurors had been filled.

\section{Amarna: An Egyptian City}

Amarna (ancient Akhetaten) offers an unusually full view of an ancient Egyptian city. Planned as the new capital by the pharaoh Akhenaten (ruled c. 13531337 BC), the city, rapidly built on previously undeveloped land, was inhabited for a short time only. Not long after Akhenaten's death, the city was abandoned in favor of Thebes and Memphis, the previously established royal centers of New Kingdom Egypt. Two factors have helped preserve this site. First, much of the city lies just inland from the flood zone of the Nile, and thus was neither covered with silt nor destroyed by farmers' ploughs. Second, the site was never rebuilt. For its short life and good preservation,
Amarna is unusual among ancient Egyptian cities. Air-dried mud brick, with stone or wood for columns and certain details, was the standard building material. Walls have melted or eroded away, with much cut building stone carried off even in New Kingdom times, but nonetheless many ground plans have been recovered. Excavations conducted from the late nineteenth century until 1936, and again since 1977, have revealed much about this city, especially about its overall layout, its city center with palaces and temples, and its suburban houses. Additional evidence for the appearance of the city comes from pictures that decorated tombs.

The city proper lay on the east bank of the Nile, its various sectors linked by a north-south road (the Royal Road) c. $8 \mathrm{~km}$ long. The territory of the city was much larger, however (an area measuring $16 \times 13 \mathrm{~km}^{2}$, marked by 14 inscribed boundary 'stelai'), that extended across the river to the western desert and included farmlands and small villages. The city was not walled. Desert cliffs to the east were used for rock-cut tombs, including, in a remote valley, that of Akhenaten himself. The population of Akhetaten has been estimated at 20000-50 000 .

The architecture documents social distinctions. First, the great social difference between ruler and ruled is clearly expressed in the contrast between the grandiose royal palaces and the houses used by everyone else. The king resided in a fortified palace in the extreme north end of the city, but the city center contained two additional palaces. The first, the Great Palace, is a huge complex used for receptions and ceremonies. Its plan consists of flat-roofed buildings, courts - notably a large court lined with colossal statues of Akhenaten - and gardens, and larger columned reception halls. Decorations included wall paintings with images of the royal family. A covered bridge across the Royal Road connected the Great Palace with the King's House, a smaller palace in which the king met with officials and dealt with day-to-day affairs. This building contained the Window of Appearances, from which the king, accompanied by his family, could address the people.

Near the palace was the Great Temple, for worship of Akhenaten's preferred deity, the Aten (life force depicted as a sun disk). Much of this large $\left(730 \times 229 \mathrm{~m}^{2}\right)$ compound was open to the sun - a contrast with the usual temple residence of Egyptian gods, a small, dark room. The open area contained several hundred offering tables. A butcher's yard and a large bakery complex located nearby contributed to the supply of offerings.

The city center also contained, in fairly symmetrical arrangement, storehouses, police barracks, and administrative buildings, including the Records 
Office in which the important Amarna Letters were found, clay tablets recording correspondence with foreign states in western Asia.

In outlying districts to the north and south of the city center, excavations of private houses have given a good idea of the lives of Amarnans of all social levels. Here overall planning was much looser than in the city center; Kemp has compared these districts to collections of villages or neighborhoods, with walled house compounds randomly arranged, interspersed with streets and garbage dumps. Houses of both rich and poor resembled each other in design, differing mainly in size. The typical house was built on a low platform inside its walled compound. The focus of the ground plan was a main hall with an adjacent twostory loggia, both with a higher roofline, held up by columns, with windows. The main room might contain a low brick platform where the owner and his wife would sit, a plastered stone washing place for water jars, and a shrine. Off this main room lay smaller rooms, bedrooms, toilets and bathrooms (from which liquid wastes drained into the ground outside), storage rooms, and stairs up to the flat roof. Outside the house, the compound would contain a garden, a well for water, servants' quarters, kitchens (with circular clay ovens for baking bread, open fires for the rest), storage areas, a shelter for animals, and a shrine to the Aten. These compounds served as economic centers, collecting food products from lands leased or owned, either near (in Amarna) or further away in the owner's home region, and for crafts or manufacturing. An example of this last is the house of the sculptor Thutmose; in his workshop was found the well-known painted bust of Queen Nefertiti.

Although Egyptian cities are otherwise poorly preserved, because of the silt covering brought by the Nile flood or subsequent rebuilding, our knowledge of the daily life of the ancient Egyptians is highly detailed. This we owe to Egyptian burial practices in which tomb decorations and grave offerings reproduce the elements of the deceased person's material world as faithfully as possible - and to the preserving qualities of the dry climate (and burials were placed in the desert areas, beyond the fertile farm lands nourished by the annual rising of the Nile). In addition, the long life of this civilization ensured that these burial concepts continued to be practiced for over 3000 years, leaving us a wealth of examples to study.

\section{Ur: A Sumerian City}

Ur, in southern Iraq, is the best known of the Sumerian cities, thanks especially to the well published excavations of Leonard Woolley (1922-1934). Ur is a 'tell', an artificial mound consisting of the accumulated remains of habitation. In the case of Ur, habitation here lasted c. 4000 years, from the fifth to the mid-first millennium BC. Since mud brick was the main building material, the mound rose higher when brick buildings went out of use and new buildings were erected on top.

The city of Ur was thus constantly renewed over a long period of time. It was large, too, occupying an area of c. 60 ha. How, then, does an archaeologist investigate a city with such a long history?

Even in the nineteenth and mid-twentieth centuries, when excavating was faster than it is now, the archaeologist could still only sample such a site. Removing each habitation layer from such a vast area would be impossible, even if the layers were neatly deposited which in reality they never are. One can only excavate where convenient, such as along the sides, or in selected areas from the top, to descend and find representative sections of the city at different periods in its long history. Thus Ur is quite different from Amarna (a single-period site), Pompeii, and the Athenian agora (where stone and baked bricks could be reused, and thus a high mound was not formed), but very typical of the ancient cities of the Near East.

The buildings excavated at Near Eastern tell sites do not survive well. If exposed to rain, the mud brick dissolves; a modern roofed structure is needed for protection, rarely provided because of high costs and practical problems. Further, the need to remove higher levels of habitation in order to sample earlier periods necessitates destruction of architecture. As a result, the modern tourist cannot expect to visit the site and step into an environment that might evoke the ancient reality - a striking contrast with, say, Pompeii. The ancient Near Eastern city typically lives on after excavation not in its built environment, which has quickly disintegrated, but in books, articles, photographs, plans, and any objects that might have been recovered (clay tablets, seals, pottery, figurines, metal objects, etc.).

Woolley's excavations yielded much information about Ur, especially about its city walls, religious center, tombs, and houses. Ur was located on a promontory between an arm of the Euphrates River and a navigable canal. Although approachable by land only from the south, the city was encircled by a mud brick wall, $27 \mathrm{~m}$ thick. These walls were built late in Ur's history, in neo-Babylonian times (sixth century BC), but surely followed the placement and appearance of earlier walls.

The religious center was dominated by a ziggurat, built by king Ur-Nammu during the prosperous Ur III period, c. 2100-2000 BC. A distinctively Mesopotamian construction, a ziggurat is a stepped pyramid made of mud brick, a series of platforms one on top of the other, each smaller than the one below, with a 
temple on top. In the flat landscape of southern Mesopotamia, it resembled a mountain, and allowed people to reach up to the gods. Unlike Egyptian pyramids, ziggurats were never tomb buildings.

Residential districts consisted of narrow, winding streets, the sign of a city developing organically over a long period of time, not planned at a single moment (see Settlement Pattern Analysis; Spatial Analysis Within Households and Sites). Houses were plain from the outside. Inside, there was a central court, with rooms around it. Woolley believed they had two stories, but this has been doubted. Most rooms opened onto the courtyard. The function of rooms is rarely certain. As at Pompeii, portable furniture must have meant that functions were constantly changing. Burials were made below the floors of the houses, in tombs of various types, with grave goods.

The most famous tombs are the 16 Royal Tombs of the Early Dynastic period, c. 2600-2350 BC, part of a large cemetery containing some 2000 graves. These graves consisted of built chambers of brick and/or stone used for multiple burials. In these tombs found intact, the deceased were accompanied by wonderful objects. Striking here was the discovery, on the ramp leading down to the chamber, of draft animals, the wheeled vehicles they pulled, and skeletons of soldiers and female attendants. The greatest number of bodies was 74. It is assumed these people were killed at the time of the burial. This practice is unique to $\mathrm{Ur}$ in this period, and not explained in any texts.

\section{Teotihuacan: A Mesoamerican City}

Do cities from a completely different tradition differ radically from the above? The aims of archaeologists in illuminating ancient daily life in the New World are certainly the same as in the Old World, and varying natures of sites and conditions of preservation mean that certain features are clearer than others.

Mesoamerica differs from the Old World presented above in that sixteenth century Spaniards were able to step into a truly different world, into the equivalent of complex societies of the ancient Mediterranean and Near East. The huge significance of this was not immediately apparent. Some descriptions were written - Bernal Díaz's eyewitness account of Tenochtitlan, the Aztec capital, is classic - but few felt the need to record in any systematic way the built environment and behavior throughout the region.

Certain ancient Mesoamerican peoples did have writing. Recent advances in understanding Mayan texts (by far the most copious) have revealed much about local dynastic histories, but other aspects of commoner Maya daily life that we might wish to learn about were not recorded. Archaeology, then, remains our best source of information about
Mesoamerican daily life (see Americas, Central: Classic Period of Mesoamerica, the Maya; Postclassic Cultures of Mesoamerica).

Cities appeared in the mid-first millennium BC, in the highland areas of the valleys of Mexico and Oaxaca. But like the long development of southwest Asian settlements during the Neolithic period, Mesoamerican cities emerged from earlier traditions, from villages, ceremonial centers, and towns found in many regions. In the Maya lowlands, urbanism began slightly later, in the late first millennium BC.

As an illustration of an ancient Mesoamerican city, let us examine Teotihuacan, in the Valley of Mexico. Teotihuacan flourished especially c. AD 150-600, thanks to its religious importance, its commercial exploitation of obsidian, its favorable position on trade routes, and agricultural prosperity in the region it dominated. The city displays a grand public built environment. It was laid out on a vast scale, as the intensive Teotihuacan Mapping Project has shown. Interestingly, the city was not walled; it is thought that its huge population and lack of nearby rivals assured its security. Two long avenues, crossing at right angles in the center, divide the city into four quadrants - a basic planning frame, off which other structures were placed in a loose grid system. The major north-south avenue, the Avenue of the Dead, is $5 \mathrm{~km}$ long; the major east-west street measures $2 \mathrm{~km}$ to the west of the crossing point, $6 \mathrm{~km}$ to the east. Considering that wheeled vehicles and pack animals were not used in ancient Mesoamerica, these are considerable distances to cover on foot. The city's area has been measured as $20 \mathrm{~km}^{2}$, its population at its height (by AD 600) estimated at over 100000 . With only one exception, it was by far the largest of all pre-Columbian New World cities; only Aztec Tenochtitlan would be more populous.

The Avenue of the Dead served as a sacred way, with three large structures on it. The Moon Pyramid marks the north end. The large Ciudadela (citadel), perhaps the administrative center of the city, with, inside it, a Temple of Quetzalcoatl in stepped pyramid form, is located at the crossing of the two major avenues; across the street to the west lies the Great Compound, possibly the central market area. The immense Sun Pyramid stands halfway between these two. Echoes of the natural world show how the inhabitants connected their built environment with natural forms. The Moon Pyramid reflects the mountain behind it. The Sun Pyramid shelters in its depths a cave (caves, like mountains, had symbolic importance in ancient Mesoamerica), used as a shrine. The pyramid temple of Quetzalcoatl is decorated with sculpted feathered serpent heads and goggled heads (fire serpents?), accompanied by sea shells, perhaps 
images of the first creation, when serpents battled in the great ocean. Below this pyramid, remains of more than 200 individuals have been found, men and women, carefully positioned sacrificial offerings unique in Mesoamerica. These features of city plan, architecture, decoration, and sacrifice indicate the cosmological importance of this city for ancient Mesoamericans - a significance that would continue to be honored into Aztec times, long after the city's collapse. Connections between the built environment and the cosmos are seen in the Old World, too - the Sumerian ziggurat, the Egyptian pyramid - but rarely with such coordinated grandeur.

The Teotihuacan Mapping Project has discovered that the city was filled with over 2000 walled residential compounds. These housing units illuminate several aspects of social life in this city. The compounds varied in size, but an average example might be $3500 \mathrm{~m}^{2}$, housing 60-100 people, living in apartments grouped around courtyards furnished with shrines. Access into the compound was controlled, thanks to a small number of entrances. Residents of a compound must have had some connection with each other - either family, or the same occupation (obsidian working was much practiced), or even, in this cosmopolitan city, place of origin (a compound for Oaxacans has been identified in the west part of the city, another for Gulf coast/ Maya lowlanders in the east). Typically, each compound had one or two rich burials in it, under the floor, with grave offerings that might include pottery, obsidian objects, and textiles.

The compounds show social differences. The larger, richer compounds centrally located close to the Avenue of the Dead may have housed the ruling class. Elsewhere, ordinary people lived in compounds of similar ground plan, but made of cheaper materials, and without decoration (such as wall paintings).

Writing was little used here - a surprise, since contacts between Teotihuacan and cities that routinely used writing (such as Monte Alban and Tikal) are clear (see Writing Systems). Because of the scarcity of writing, we might hope that pictorial art might give some clues about the society, about daily life. Wall paintings, a frequent decoration in the compounds, show supernatural beings, especially the goggled storm god and a 'goddess'. Images stress harmony and agricultural plenty. Humans, when they occur, are anonymous, shown in profile, in procession. Rulers are never shown, neither in the murals nor in other arts. This absence of ruler portraits and images of power contrasts with art in Mayan cities, in which rulers are presented on carved stelai, or at Monte Alban, with its Danzantes (Dancers) reliefs, images not of dancers but of enemy dead. In sum, pictorial art does give information about ideologies in favor at Teotihuacan, but presents nothing that chronicles specific people and their accomplishments.

Teotihuacan is not typical of Mesoamerican cities, but then neither is Monte Alban or Tikal. In any case, the same themes of daily life that we list for Old World cities can be applied to the New World as well - with, as always, each site providing certain types of information, but not others.

See also: Americas, Central: Classic Period of Mesoamerica, the Maya; Postclassic Cultures of Mesoamerica; Anthropological Archaeology; Asia, West: Mesopotamia, Sumer, and Akkad; Civilization and Urbanism, Rise of; Europe, South: Greece; Historic Roots of Archaeology; Household Archaeology; Settlement Pattern Analysis; Spatial Analysis Within Households and Sites; Urban Archaeology; Volcanism and Archaeology; Writing Systems.

\section{Further Reading}

Camp JM (1986) The Athenian Agora. Excavations in the Heart of Classical Athens. London and New York: Thames \& Hudson.

Camp JM (2001) The Archaeology of Athens. New Haven: Yale University Press.

Gates C (2003) Ancient Cities. London: Routledge.

Grant M (1971) Cities of Vesuvius: Pompeii and Herculaneum. New York: Macmillan.

Kemp BJ (1989) Ancient Egypt: Anatomy of a Civilization, pp. 261-317. New York: Routledge.

Marcus J (1983) On the nature of the Mesoamerican city. In: Vogt EZ and Leventhal RM (eds.) Prehistoric Settlement Patterns. Essays in Honor of Gordon R. Willey, pp. 195-242. Albuquerque, NM, and Cambridge, MA: University of New Mexico Press and Peabody Museum of Archaeology and Ethnology, Harvard University.

Sabloff JA (1989) The Cities of Ancient Mexico. Reconstructing a Lost World. New York: Thames \& Hudson.

Woolley CL (1982) Ur of the Chaldees, revised by Moorey PRS. Ithaca, NY: Cornell University Press.

Zanker P (1998) Pompeii. Public and Private Life, Schneider DL (trans.). Cambridge, MA: Harvard University Press. 